\title{
GATA4 wt Allele
}

National Cancer Institute

\section{Source}

National Cancer Institute. GATA4 wt Allele. NCI Thesaurus. Code C75496.

Human GATA4 wild-type allele is located within 8p23.1-p22 and is approximately $56 \mathrm{~kb}$ in length. This allele, which encodes transcription factor GATA-4 protein, plays a role in the modulation of both transcription and cardiovascular development. Mutation of the gene is associated with atrial septal defect type 2 . 